\title{
Diseminasi Budidaya Padi Gogo, Jagung, dan Kacang Tanah Sistem Agroforestri Berbasis Tegakan Sengon di KPH Blitar
}

\author{
Djoko Purnomo $^{1 *}$, MTh Sri Budiastuti ${ }^{1}$, Amalia Tetrani Sakya ${ }^{1}$, Anang Susanto ${ }^{2}$ \\ ${ }^{1}$ Program Studi Agroteknologi, Fakultas Pertanian, Universitas Sebelas Maret \\ ${ }^{2}$ Fakultas Pertanian, Universitas Merdeka, Madiun \\ *Corresponding Author: djokopurnomo@staff.uns.ac.id
}

\begin{abstract}
ABSTRAK
Tujuan kegiatan pengabdian adalah memberikan informasi teknologi budidaya padi gogo, jagung dan kacang tanah di bawah tegakan sengon, khususnya dalam perolehan cahaya, sehingga tanaman di bawah tegakan dapat tumbuh dan memberikan hasil yang optimal. Hal ini dilakukan karena selama ini hasil yang diperoleh tanaman di bawah tegakan belum maksimal. Pengabdian diselenggarakan mulai bulan Oktober sampai Desember 2018 di desa Maliran, Kecamatan Ponggok, Kabupaten Blitar dengan melibatkan pihak perhutani dan masyarakat di sekitar hutan (petani agroforestri). Kegiatan pengabdian meliputi pembuatan demplot, penyuluhan dan diskusi (focus group discussion/FGD) yang dilaksanakan di kantor KBH Blitar dengan melibatkan pihak Perhutani dan petani. Pembuatan demplot dilakukan dengan penanaman jagung, padi gogo dan kacang tanah di bawah tegakan sengon umur 3, 4, dan 5 tahun. Hasil FGD diperoleh kesepakatan bahwa diperlukan pemangkasan kanopi pohon bagian bawah sepertiga dari tinggi kanopi. Hal ini diperlukan sebagai upaya menyediakan cahaya bagi tanaman di bawah tegakan saat sengon mencapai umur di atas 3 tahun, sehingga tanaman di bawah tegakan dapat tumbuh dan memberikan hasil yang optimal. Dari hasil demplot menunjukkan padi gogo dan jagung yang ditanam pada tegakan sengon umur lebih dari 3 tahun tanpa pemangkasan tidak memberikan hasil, tetapi kacang tanah masih dapat menghasilkan. Setelah terlibat langsung dalam kegiatan demplot, petani menyatakan bahwa pemangkasan kanopi memberikan wawasan baru dalam melakukan budidaya di bawah tegakan pohon. Selain itu, juga diperoleh informasi bahwa seresah sengon dapat digunakan sebagai pupuk hijau, dan tanaman kacang-kacangan (legum) sangat potensial sebagai tanaman sela, serta tanaman dibawah tegakan dapat digunakan sebagai alternatif sumber pangan organik.
\end{abstract}

Kata kunci: agroforestri, jagung, kacang tanah, padi, sengon

\section{ABSTRACT}

The aim of community service to provides information technology on the cultivation of gogo rice, maize, and groundnut under the sengon stand, especially in the acquisition of light to grow and provide optimal yields. This is done because, during that time, plant yields under the stand have not been maximized. The community service activities were carried out from October to December 2018 in Maliran village, Ponggok District, Blitar Regency, involving farmers and communities around the forest (agroforestry farmers). Devotional activities include making demonstration plots, counseling, and discussion (focus group discussion/FGD). The discussions obtained an agreement that required pruning the lower tree canopy amounting to one-third of the height of the canopy. The pruning was necessary to provide light for plants under the stand when sengon reaches the age over 3 years so that the plants under sengon stands could grow and give optimal yield. The demonstration plot showed that gogo rice and maize grown on sengon stands over 3 years without pruning did not give any product, but groundnut can still produce. After being involved in the demonstration plot, farmers stated that the pruning method adds insight into crop cultivation under the stand. Besides, it is also obtained that litter can be used as green manure, and legume crops are potential as an intercropped plant. Plant under sengon stand can be used as an alternative source of organic food.

Keywords: Agroforestry, corn, peanut, paddy, sengon (Paraserianthes falcataria) 


\section{PENDAHULUAN}

Budidaya tanaman secara tumpangsari telah biasa dilakukan oleh para petani di Indonesia, terutama di Jawa, tidak hanya antara tanaman semusim tetapi juga di antara tanaman semusim dan tahunan (pepohonan). Tumpangsari antara tanaman semusim dan tahunan sudah berlangsung sejak manusia melakukan domestikasi baik tumbuhan maupun hewan kemudian dipelihara di dekat rumah yang kemudian disebut pekarangan (Badan Ketahanan Pangan, 2018). Teknologi budidaya yang dilakukan pada sistem pekarangan sangat sederhana dan hanya bertujuan untuk memenuhi kebutuhan sehari-hari, antara lain: sebagai bahan makanan ringan (camilan), sayur, bumbu, lauk hasil ternak dan atau ikan, serta obat herbal (Mellisse et al., 2017). Peningkatan jumlah penduduk dan perkembangan ekonomi mengakibatkan lahan pertanian banyak berubah menjadi peruntukan lain padahal kebutuhan pangan semakin besar. Kawasan hutan menjadi alternatif sebagai pengganti lahan pertanian dengan budidaya tanaman di antara tegakan pohon yang dinamakan sistem agroforestri (AF) (Budiastuti \& Purnomo, 2012; Van Noordwijk et al., 2016) Petani di kawasan hutan, memanfaatkan lahan di bawah tegakan yang bertujuan untuk menciptakan keragaman hasil dan meningkatkan pendapatan (Rachman \& Hani, 2014; Arifin et al., 2014; Wahyu et al., 2018).

Sengon merupakan salah satu tegakan hutan yang sering dimanfaatkan untuk sistem AF. Hasil penelitian penerapan sistem AF pada tegakan sengon menunjukkan produktivitas lahan yang lebih tinggi dibandingkan dengan penanaman secara monokultur (Rachman \& Hani, 2014). Pertumbuhan tanaman bawah yaitu padi gogo dengan pemupukan $\mathrm{P}$ memberikan hasil yang lebih tinggi dibanding tanpa pemupukan pada sistem monokultur (Ningrum et al., 2019). Penelitian lain menunjukkan bahwa penggunaan varietas kedelai toleran naungan pada agroforestri sengon 4 tahun yang menghasilkan produksi lebih rendah dari hasil di lahan terbuka (Hartoyo et al., 2014, 2015). Selain itu, penanaman sengon (Paraserianthes falcataria) juga dapat meningkatkan kualitas kesuburan tanah (Khalif et al., 2014).

Petani (sekitar 241 orang) yang merupakan masyarakat desa hutan melakukan budidaya tanaman di antara tegakan sengon di Kesatuan Pemangkuan Hutan (KPH) Blitar seluas 35.442 ha (61\%). Saat ini petani di kawasan hutan secara legal melaksanakan program Pengelolaan Hutan Bersama Masyarakat (PHBM) sebagai suatu sistem pengelolaan sumberdaya hutan. Program yang dilaksanakan merupakan pengelolaan hutan bersama antara Perum Perhutani dan masyarakat desa hutan dan atau antara Perum Perhutani, dan masyarakat desa hutan, serta pihak yang berkepentingan (stakeholder) untuk keberlanjutan fungsi dan mencapai manfaat secara optimum. Sejak tahun 2001 program PHBM diubah menjadi program Pembangunan Masyarakat Desa Hutan Terpadu (PMDHT) melalui perhutanan sosial yang berkoordinasi dengan pemerintah daerah. Tanaman budidaya di lahan tersebut antara lain: nanas, jagung, padi, dan kacang tanah, yang menggunakan teknologi seperti menanam di lahan terbuka. Oleh karena itu, hasil tanaman tersebut jauh lebih rendah daripada di lahan pertanian konvensional (informasi petani). Hasil tanaman di sistem AF lebih rendah daripada di lahan konvensional karena terteduhi oleh kanopi pohon. Melalui penelitian, rekayasa pengaturan jarak pohon dan kanopi dapat dilakukan sebagai peningkatan intensitas cahaya bagi tanaman (Purnomo et al., 2013).

Teknologi budidaya tanaman dalam sistem AF memerlukan pemahaman, baik oleh pengelola hutan maupun petani. Perhutani melarang petani menanam tanaman setelah sengon berumur 3 tahun untuk mengurangi potensi terjadinya gesekan antara kedua pihak tersebut. Dibandingkan pohon lain, sengon meloloskan cahaya lebih tinggi karena kanopi (tajuk) memiliki daun kecil, mudah rontok, dan pola percabangan relatif teratur (Susanto et al., 2018). Peningkatan cahaya lolos dari kanopi pohon umur di atas 3 tahun dapat dilakukan melalui pemangkasan ranting dan daun bagian bawah pada sepertiga tinggi kanopi (Affandi $e t$ al., 2019). Selain cahaya, kebutuhan $\mathrm{N}$ tanaman memerlukan perhatian, dimana tanaman kedelai pada sistem AF dalam memenuhi kebutuhan $\mathrm{N}$ bergantung pada fiksasi $\mathrm{N}_{2}$. Adapun ketersediaan air hasil penelitian menunjukkan bahwa produksi kedelai pada sistem AF lebih stabil dibandingkan pada sistem monokultur dengan kondisi curah hujan yang terbatas (Nasielski et al., 2015). Selain itu, pada kondisi cahaya rendah dapat menggunakan tanaman toleran atau menambah dosis nitrogen.

$$
\text { Dengan inovasi teknologi dalam }
$$
pengelolaan tegakan sengon, khususnya 
pengaturan cahaya, memungkinkan tanaman di bawah tegakan sengon dapat tumbuh secara optimal. Namun, selama ini petani yang melakukan budidaya tanaman dalam sistem $\mathrm{AF}$ masih seperti di pertanaman tunggal. Hal ini mengakibatkan petumbuhan tanaman tidak optimal dan hasil yang diperoleh rendah. Pemahaman pengelolaan dalam sistem AF yang berbeda antara Perhutani dan petani juga merupakan kendala tersendiri. Berdasarkan masalah tersebut, kegiatan pengabdian pada masyarakat di KPH Blitar diselenggarakan dengan sasaran pengelola hutan sengon dan petani AF. Kegiatan pengabdian diadakan dengan tujuan pengelola dan petani $\mathrm{AF}$ mendapatkan informasi yang sama dalam budidaya tanaman pangan di bawah tegakan sengon. Kesepakatan dalam pengelolaan tanaman di bawah tegakan sengon akan memperoleh hasil optimum dan memberikan gambaran potensi tanaman pangan yang diusahakan di bawah tegakan serta pemanfaatan seresah sengon.

\section{METODE}

Pengabdian pada masyarakat diselenggarakan di kawasan hutan sengon di bawah pengelolaan KPH Blitar Perum Perhutani Unit II Jawa Timur pada bulan OktoberDesember 2018. Waktu tersebut bertepatan dengan awal musim penghujan, saat para petani sedang mempersiapkan penanaman di bawah tegakan sengon. Pengairan tidak tersedia di kawasan tersebut, keperluan air pertanaman tergantung pada hujan. Peserta pengabdian terdiri atas pegawai Perhutani, masyarakat/petani desa Maliran, Kecamatan Ponggok, Kabupaten Blitar yang berdomisili di sekitar hutan. Pegawai Perhutani atas nama pemegang kebijakan ditugaskan untuk menjaga agar budidaya tanaman (oleh petani) memenuhi kaidah agronomi, namun tetap mengikuti ketentuan. Petani AF sebagian besar adalah masyarakat yang tinggal di sekitar hutan. Masyarakat tersebut secara turun temurun mencari kayu bakar, berburu binatang liar, dan memanen tumbuhan liar di dalam hutan.

Pelaksanaan pengabdian meliputi identifikasi lokasi dan umur tegakan sengon, pelaksanaan demplot (demonstration plot), pendampingan petani dalam melakukan budidaya tanaman, dan forum diskusi kelompok atau FGD (forum group discussion). Demplot dilakukan untuk memberikan gambaran secara langsung budidaya padi gogo, jagung dan kacang tanah dibawah tegakan sengon dengan inovasi teknologi antara lain pemilihan varietas tanaman, pemupukan, dan pemangkasan pohon. Demplot dilakukan di 3 lokasi pada tegakan sengon umur 3, 4 dan 5 tahun. Demplot melibatkan msyarakat dan perwakilan Perhutani. Pendampingan dimulai saat petani melakukan pengolahan tanah, persiapan bibit, penanaman, pemeliharaan (pemupukan, pendangiran, penyiangan, pengendalian organisme pengganggu tanaman/OPT), hingga panen. Diskusi kelompok (FGD) terbagi menjadi tiga tahap, pertama diskusi dengan pihak Perhutani (diwakili oleh petugas lapangan) tentang program PMDHT dengan komponen Perhutanan Sosial. Di dalam program tersebut terdapat tata kelola (perjanjian dan peraturan) penggunaan lahan kawasan hutan oleh petani. Kedua, diskusi dengan petani tentang potensi dan kendala budidaya sistem $\mathrm{AF}$, dan ketiga diskusi bersama antara UNS, Perhutani, dan petani.

Evaluasi dilakukan berdasarkan keikutsertaan dalam praktik demplot dan peran serta dalam forum diskusi. Di setiap lokasi demplot sekelompok petani (sekitar 5 orang) terlibat sejak dari pengolahan tanah, penanaman, pemeliharaan, hingga panen. Keterlibatan petani dalam kegiatan tersebut yang berada di 3 lokasi terkoordinasi oleh pegawai Perhutani menggunakan presensi kehadiran. Keterlibatan tersebut yaitu dalam kegiatan demplot dan FGD.

\section{HASIL DAN PEMBAHASAN}

\section{Kondisi aktual}

Hutan sengon di desa Maliran, seluas sekitar 34 ha, sebagian besar telah dimanfaatkan oleh petani di sekitar hutan (132 KK) untuk budidaya nanas, jagung, kacang tanah, dan padi. Budidaya tanaman tersebut di bawah tegakan sengon masing-masing menghasilkan sekitar 6,$5 ; 2,0 ; 0,83$; dan 2,7 ton ha $^{-1}$. Umur tanaman masing-masing $12 ; 4 ; 3$; dan 5 bulan. Hasil yang dicapai relatif sangat rendah karena teknologi budidaya sangat sederhana, antara lain pupuk berdosis rendah dan pemeliharaan lain jauh di bawah intensif. Perbedaan tegakan sengon (bukan AF) dan sengon berbasis sistem $\mathrm{AF}$ menunjukkan bahwa petani melakukan pemangkasan pohon tanpa pola untuk memenuhi cahaya bagi tanaman (Gambar 1). 


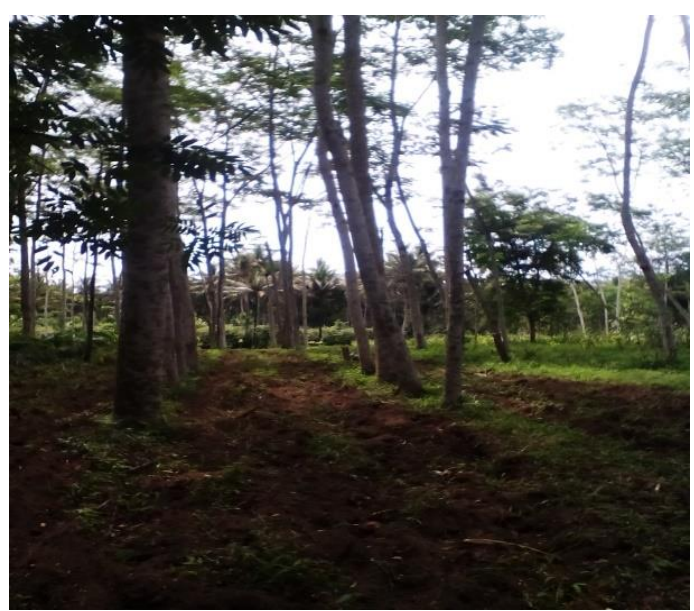

A

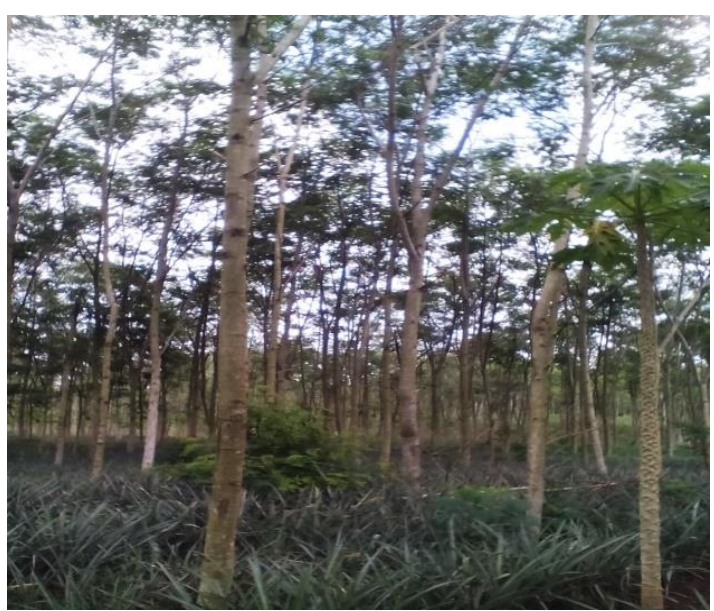

B

Gambar 1. Tegakan Sengon (A) dan Sistem AF Nanas Berbasis Sengon (B)

\section{Pelaksanaan demplot}

Kegiatan pengabdian diawali dengan peninjauan kondisi lapangan sekaligus berdiskusi dengan petugas perhutani untuk membahas budidaya sistem AF serta penentuan lahan untuk pelaksanaan demplot (Gambar 2). Pelaksanaan demplot melibatkan petani AF di sekitar hutan yang ditujukan untuk memberi gambaran secara langsung inovasi teknologi yang akan diberikan. Petani terlibat sebagai tenaga penggarap sejak dari pengolahan tanah, persiapan bibit, penanaman, pemeliharaan (pemupukan, pendangiran, penyiangan, pengendalian organisme pengganggu tanaman/OPT), hingga panen.

Pada kegiatan demplot, petani juga diminta untuk menampung seresah sengon yang terdiri dari daun dan ranting yang luruh dari setiap petak demplot dengan luasan $100 \times 100$ $\mathrm{cm}$. Hal ini untuk memberi gambaran kepada petani bahwa seresah yang terkumpul selama satu musim tanam dapat digunakan untuk penambahan hara terutama $\mathrm{N}$.

Pelaksanaan demplot dilakukan pada tegakan sengon berumur 3, 4 dan 5 tahun dan di setiap tegakan ditanam tanaman pangan yaitu padi gogo, kacang tanah dan jagung. Pada setiap lahan juga dilakukan pemangkasan pohon sengon bagian bawah pada 1/3 tinggi kanopi untuk mendapatkan gambaran inovasi pemangkasan terhadap pertumbuhan dan hasil tanaman pangan yang ditanam di bawah tegakan sengon. Hasil yang diperoleh dari demplot digunakan untuk berdiskusi lebih lanjut baik dengan petugas Perhutani maupun petani. Petani yang terlibat di setiap kelompok memberikan pendapat dan penjelasan tentang tanaman yang dibudidayakan. Berdasarkan pelaksanaan dan hasil demplot, saat FGD petani saling memahami permasalahan budidaya untuk setiap tanaman di setiap lokasi.

\section{Diskusi dengan petugas Perhutani}

Dalam budidaya sistem AF Perum Perhutani hanya mengijinkan petani menanam tanaman hingga sengon berumur tiga tahun. Peraturan tersebut berlaku secara nasional karena berdasarkan pengalaman di tegakan lain (jati, karet, dan pinus) sebelum program PMDHT diselenggarakan, petani berusaha memperbesar kebutuhan cahaya untuk tanaman namun mengabaikan fungsi hutan. Saat awal penanaman, pohon ditanam dalam jarak rapat, kemudian diperjarang sampai beberapa kali sehingga pohon tinggi tidak banyak cabang. Hal itu untuk memperoleh nilai ekonomi tinggi karena hasil kayu lurus, silindris (diameter ujung dan pangkal hampir sama), dan tidak banyak mata (soca). Tujuan ekologi dan produksi hutan masih akan tercapai apabila sistem AF tetap berlangsung dengan pengaturan jarak pohon yang lebih teratur dan pemangkasan bagian bawah pada 1/3 tinggi kanopi yang sesuai dengan peningkatan umur pohon. Pemangkasan kanopi bagian bawah tidak mengganggu pertumbuhan pohon karena daun sudah tidak efektif lagi sebagai organ fotosintesis (ternaungi daun bagian atas, umur sudah tua, warna menguning yang berarti kandungan khlorofil rendah). Pengaturan jarak pohon (menjadi lebih rapi) tidak sulit dilaksanakan, namun mengubah peraturan memerlukan kekuatan dari luar seperti Pemda atau lembaga legislatif. Adapun dengan pemangkasan kanopi, meskipun belum legal, tidak sulit dilaksanakan karena tidak mengganggu pertumbuhan. 


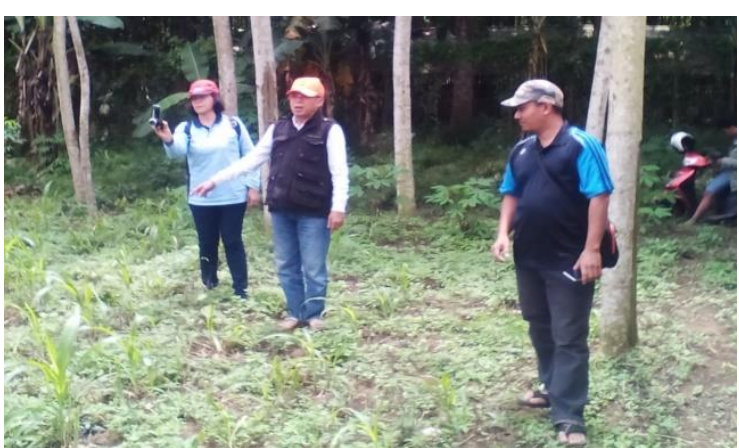

Gambar 2. Diskusi dengan Petugas Perhutani di lapangan

\section{Diskusi dengan petani}

Selain berdiskusi dengan pihak Perhutani, untuk pelaksanaan demplot agroforestri juga dilakukan diskusi dengan pihak petani (Gambar 3). Sejak Perhutani mengeluarkan program PHBM kemudian menjadi PMDHT, masyarakat desa hutan secara legal melakukan budidaya tanaman di kawasan hutan. Selain memperoleh tambahan pendapatan dari hasil tanaman, meskipun tidak memiliki lahan pertanian, petani AF merasa tenang dan nyaman. Namun demikian, karena tanaman ternaungi pohon, petani berusaha meningkatkan cahaya lolos dari kanopi dengan pemangkasan tanpa pola yang menimbulkan gangguan pada pohon. Saat diskusi, petani memahami aturan Perhutani yang memberikan penjelasan bahwa pemangkasan kanopi dapat dilakukan pada bagian bawah sepertiga tinggi kanopi. Petani menyambut gembira karena dapat memperpanjang budidaya di AF berbasis sengon (secara normal sengon ditebang umur 8 tahun). Tanpa pemangkasan kanopi, jagung dan padi (gogo) cenderung gagal panen di bawah tegakan sengon umur tiga tahun, namun kacang tanah masih menghasilkan.

Selain pemangkasan pohon, saat diskusi juga dijelaskan bahwa sengon termasuk tumbuhan legum yang meningkatkan kesuburan tanah terutama N. Karena itu bertanam di bawah tegakan sengon dapat mengurangi penggunaan pupuk N (mis. urea). Unsur lain (P dan $\mathrm{K}$ ) juga dapat terpenuhi karena seluruh cabang dan ranting sengon langsung dapat dikembalikan ke lahan (tanpa proses pengomposan sehingga disebut pupuk hijau). Kondisi demikian memungkinkan sistem AF berbasis sengon menghasilkan bahan pangan organik. Melalui perencanaan dan pengujian jika hasil dinyatakan sebagai bahan pangan organik, maka hasil tersebut mempunyai keunggulan ekonomi (harga relatif tinggi). Hal ini yang harus dikembangkan oleh petani secara berkelompok sehingga perlu dibentuk kelompok tani desa hutan, dan jika sudah ada maka perlu adanya penguatan.

\section{Diskusi bersama petani dan Perhutani}

Diskusi bersama antara petani dan perhutani memberikan gambaran mengenai kemanfaatan agroforestri antara tanaman pangan dan sengon (Gambar 4). Sebelum diskusi dilakukan, pada kesempatan berkumpulnya petani dan petugas perhutani juga dilakukan transfer ilmu yang diberikan oleh tim pengadian masyarakat. Transfer ilmu yang diberikan meliputi optimalisasi cahaya lolos dari kanopi, pemilihan tanaman toleran intensitas cahaya rendah, optimalisasi pupuk $\mathrm{N}$ dalam kondisi intensitas cahaya rendah, dan pengelolaan seresah pohon sebagai pupuk hijau, serta penyesuaian masa tanam dengan ketersediaan air.

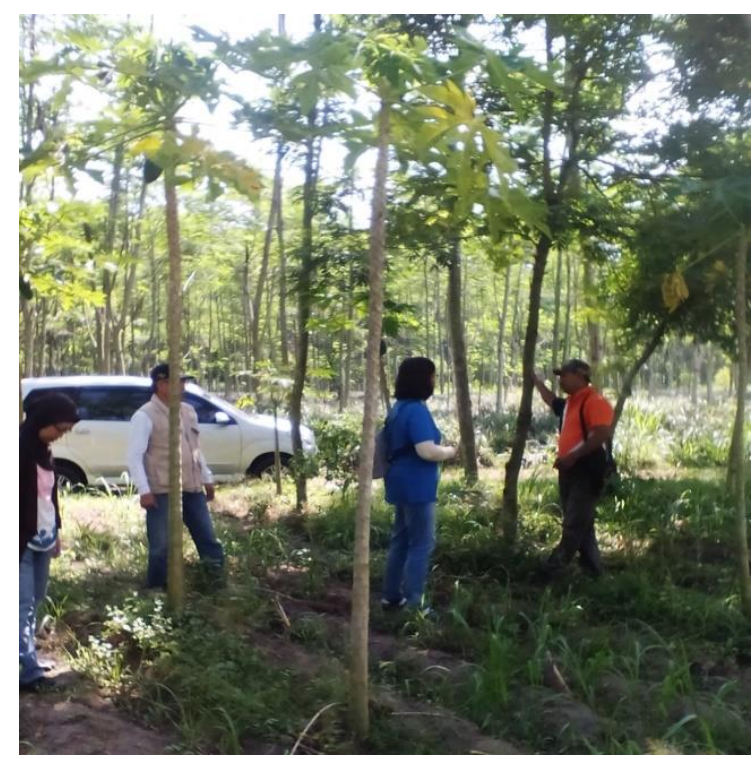

Gambar 3. Diskusi dengan petani masyarakat desa hutan

Dalam diskusi, petani mengemukakan harapannya agar dapat melakukan budidaya tanaman sistem AF lebih panjang (sekitar 4-5 tahun). Secara teknik untuk memperoleh pencahayaan bagi tanaman, dicapai kesepakatan bahwa petani dapat melakukan pemangkasan kanopi pohon. Pemangkasan kanopi bagian bawah 1/3 tinggi dapat dipahami oleh pihak Perhutani dan petani, sehingga kerusakan pohon dapat dihindari. Namun secara administratif (legalisasi) perlu penjelasan ke pimpinan Perhutani. Budidaya tanaman di antara tegakan sengon berpotensi menghasilkan bahan pangan organik. Ini perlu tindak lanjut ke badan 
akreditasi produk organik, melalui serangkaian kegiatan, sehingga sertifikat pangan organik dapat diperoleh. Selain budidaya tanaman, di area yang tidak memungkinkan budidaya tanaman (lahan kering, miring, atau pohon menjelang tebang), dapat dilakukan budidaya ternak. Apabila tersedia air yang mencukupi, maka dapat dibuat kolam untuk budidaya ikan di bawah tegakan (silvofisheri).
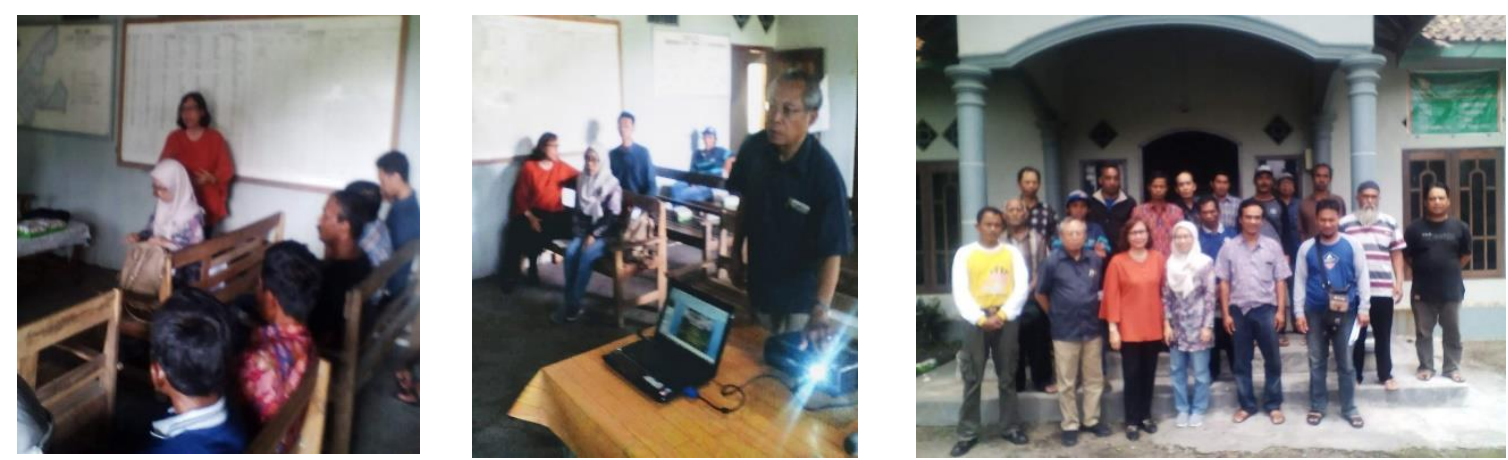

Gambar 4. Diskusi dengan petani dan Perhutani

\section{Evaluasi}

Berdasarkan pengamatan yang dilakukan oleh tim pengabdian, diketahui bahwa kegiatan pengabdian yang dilakukan dengan metode demplot dan FGD mendapatkan tanggapan yang positif dari peserta pengabdian. Hal ini terlihat dari antusiasme peserta yang tinggi pada pelaksanaan demplot dan jumlah pertanyaan dari peserta kepada tim pengabdi baik pada saat pelaksanaan demplot ataupun saat FGD. Penyampaian materi mengenai optimalisasi cahaya lolos dari kanopi, pemilihan tanaman toleran intensitas cahaya rendah, optimalisasi pupuk $\mathrm{N}$ dalam kondisi intensitas cahaya rendah, dan pengelolaan seresah pohon sebagai pupuk hijau, serta penyesuaian masa tanam dengan ketersediaan air dilaksanakan secara singkat dan jelas, serta didukung media alat bantu LCD yang mendukung peserta untuk terlibat secara aktif pada saat pelaksanaan FGD. Dari hasil keterlibatan pada saat demplot, petani dan petugas lapangan perhutani mendapatkan persepsi yang sama mengenai manfaat pemangkasan kanopi sengon bagian bawah untuk menyediakan cahaya yang cukup bagi tanaman di bawah tegakan sengon.

\section{KESIMPULAN}

Kegiatan pengabdian yang meliputi demplot, pendampingan dan FGD dapat memberikan transfer teknologi budidaya, khususnya pengelolaan cahaya dalam pengelolaan sistem AF pada tegakan sengon. Pada saat FGD diperoleh kesepakatan antara para petani dan aparatur lapangan Perhutani, bahwa perlu adanya pemangkasan kanopi pohon bagian bawah sebesar sepertiga dari tinggi kanopi. Pemangkasan diperlukan untuk memberikan ketersediaan cahaya bagi tanaman di bawah tegakan sengon saat sengon mencapai umur di atas 3 tahun. Selain itu, peserta juga mendapatkan informasi mengenai manfaat dari seresah sengon (daun dan cabang) yang dapat digunakan sebagai pupuk hijau, serta tanaman legum yang sangat potensial sebagai tanaman sela dan kemungkinan hasil tanaman di bawah tegakan sebagai bahan pangan organik.

\section{UCAPAN TERIMA KASIH}

Penulis menyampaikan terima kasih kepada UNS sebagai penyandang dana melalui hibah kompetisi PNBP (No Kontrak: 543/UN27.21/PP/2018), serta pihak Perhutani dan petani di wilayah KPH Blitar.

\section{DAFTAR PUSTAKA}

Affandi, Z., Purnomo, D., \& Supriyono, S. (2019). A Study of Light Intensity and Fertilizer on Soybean in Albizia chinensis Agroforestry System. SAINS TANAH Journal of Soil Science and Agroclimatology, $\quad$ 16(1), 46. https://doi.org/10.20961/stjssa.v16i1.2587 2

Arifin, H. S., Wulandari, C., Pramukato, Q., \& Kaswanto, R.L. (2014). Analisis Lanskap Agroforestri: Konsep, Metode, dan Pengelolaan Agroforestri Skala Lanskap dengan Studi Kasus Indonesia, Filipina, Laos, Thailand, dan Vietnam. IPB Press.

Budiastuti, M. S., \& Purnomo, D. (2012). 
Agroforestri, untuk pengelolaan lahan berwawasan lingkungan. UNS Press.

Hartoyo, A. P. P., Wijayanto, N., \& Budi, R. S. W. (2014). Respon Fisiologi dan Produksi Kedelai (Glycine max ( L .) Merrill) Toleran Naungan Berbasiskan Agroforestri Sengon ( Paraserianthes falcataria ( L .) Nielsen ) The Physiological Response and Production of Soybeans ( Glycine max ( L .) Merrill ) Tolerant. Jurnal Silvikultur Tropika, 05(2), 84-90.

Hartoyo, A. P. P., Wijayanto, N., \& Budi, R. S. W. (2015). Pertumbuhan dan Produksi Kedelai (Glycine max (L.) Merrill) Berbasiskan Agroforestri Sengon (Paraserianthes falcataria ( L .) Nielsen ). Seminar Nasional Agroforestry, November 2015.

Khalif, U., Utami, S., \& Kusuma, Z. (2014). Pengaruh Penanaman Sengon (paraserianthes faccataria) terhadap kandungan $\mathrm{C}$ dab $\mathrm{N}$ Tanah di Desa Slamparejo, Jabung, Malang. Jurnal Tanah Dan Suumberdaya Lahan, I(1), 9-15.

Mellisse, B. T., van de Ven, G. W. J., Giller, K. E., \& Descheemaeker, K. (2017). Home garden system dynamics in Southern Ethiopia. Agroforestry Systems, 92(6), 1579-1595. https://doi.org/10.1007/s10457-017-01065

Nasielski, J., Furze, J. R., Tan, J., Bargaz, A., Thevathasan, N. V., \& Isaac, M. E. (2015). Agroforestry promotes soybean yield stability and N2-fixation under water stress. Agronomy for Sustainable Development, 35(4), 1541-1549. https://doi.org/10.1007/s13593-015-0330-
Ningrum, D., Wijayanto, N., \& Wulandari, A. (2019). Pertumbuhan Sengon dan Produksi Padi Gogo Pada Taraf pemupukan P yang Berbeda dalam Sistem Agroforestri. Jurnal Silvikultur Tropika, 10(01), 1-6.

Pangan, B. K. (2018). Petunjuk Teknis Optimalisasi Pemanfaatan Lahan Pekarangan Melalui Kawasan Rumah Pangan Lestari (KRPL).

Purnomo, D., Sitompul, S., \& Budiastuti, M. (2013). Solar radiation in agro-forestry system. Journal of Biotechnology and Biodiversity, 1(1), 14-19.

Rachman, E., \& Hani, A. (2014). Pola Agroforestry Sengon (Falcataria moluccana L.) dan Cabai Merah Keriting Di Dataran Tinggi Ciamis Jawa Barat. Penelitian Agroforestry, 2(1), 35-44.

Susanto, A., Mujiyo, M., Purnomo, D., \& Budiastuti, Mt. S. (2018). Characteristics of sengon (Paraserianthes falcataria) stands in forest Blitar. International Journal of Forest, Animal and Fisheries Research, 2(3), 108-112. https://doi.org/10.22161/ijfaf.2.3.3

Van Noordwijk, M., Coe, R., \& Sinclair, F. (2016). Central hypotheses for the third agroforestry paradigm within a common definition (No. 233).

Wahyu, I., Pranoto, H., \& Supriyanto, B. (2018). Kajian Produktivitas Tanaman Semusim pada Sistem Agroforestri di Kecamatan Samboja Kabupaten Kutai Kartanegara Cash Crop Productivity Analysis of Agroforestry System in Samboja , Kutai Kartanegara District. Jurnal Agroekoteknologi Tropika Lembab, 1(1), 24-33. 